\title{
Food futuring in Timor-Leste: Recombinance, responsiveness, and relationality
}

\author{
David Szanto* \\ Carleton University
}

Submitted June 2, 2021 / Revised September 9 and November 3, 2021 / Accepted November 9, 2021 /

Published online February 24, 2022

Citation: Szanto, D. (2022). Food futuring in Timor-Leste: Recombinance, responsiveness, and

relationality. Journal of Agriculture, Food Systems, and Community Development, 11(2), 89-111.

https://do1.org/10.5304//atscd.2022.112.012

Copyright (C) 2022 by the Author. Published by the Lyson Center for Civic Agriculture and Food Systems. Open access under CC-BY license.

\begin{abstract}
The pluralistic nature of food culture and food systems produces complex and blended realities for research, often prompting approaches that embrace mixed methods and cross-sector partnerships. In parallel, calls for the decolonization of research methods have brought attention to the importance of relationality when working with local communities and traditional knowledge holders. This article presents the process and outcomes of the Timor-Leste Food Innovators Exchange (TLFIX), a multifaceted initiative centered on the contemporary and historic foodways of TimorLeste, including current challenges to individual health, cultural identity, and economic-ecological sustainability brought about by centuries of colonial and transnational influence. Conceived within an international development context, TLFIX
\end{abstract}

\footnotetext{
* David Szanto, Postdoctoral Researcher, Carleton University. David Szanto is now at l'Université d'Ottawa, Faculty of Arts; Simard Hall, 60 University; Ottawa, ON, K1N 6N5 Canada; dszanto@uottawa.ca
}

aimed at building local empowerment, economic development, and social change. Methods included quantitative, qualitative, and material-based approaches, including surveys, storytelling, and culinary innovation. As a "consulting academic" on the project, I contributed to the research design, coached team members on storytelling-as-method, and participated in a portion of the work. For the current text, I use the notions of recombinance, responsiveness, and relationality to interpret our collective experience and to frame an example of carrying out

\footnotetext{
Author Note and Funding Disclosure

The bulk of this text was written during a postdoctoral fellowship with the Food: Locally Embedded, Globally Engaged (FLEdGE) partnership, which was supported by the Social Sciences and Humanities Research Council of Canada. Funding for the 2018 research came from innovationXchange (LAUNCH Food grant \#LAUNCH012), which is supported by USAID and Australia's Department of Foreign Affairs and Trade (DFAT). My initial contact with Alva Lim and Mark Notaras took place in 2016 through the Eco-Gastronomy Project, which was funded and supported by the University of Gastronomic Sciences and Slow Food International.
} 
mixed-method and mixed-participant work in complex food contexts. As a whole, this example illustrates ways in which to leave space for improvisation and emergence within food practice and scholarship.

\section{Keywords}

Timor-Leste, Foodways, Relationality, Localness, Improvisation, Decolonization, Culinary

Innovation

\section{Introduction}

Food scholarship that involves material practicegrowing, processing, cooking, serving, eating, disposing-presents a range of challenges to positivist academic conventions (Atkins, 2010; de Solier, 2013; D. Miller, 2005; Szanto, 2016). While food systems are often studied through disciplinary frameworks such as sociology, economics, biology, and geography, the material nature of food itself tends to blur disciplinary lines while implicating pluralistic, sensory, and embodied forms of knowledge, including those that resist textual description. In response, some food scholars have adopted hybrid models that bridge sectors, enable partnerships with on-the-ground practitioners, and highlight transdisciplinarity (de Marchi, 1999; Levkoe et al., 2016; Strand et al., 2003). Adding to such hybridity, fields such as sensory studies, ecofeminism, and Indigenous studies have contributed paradigms to food studies that support a "performative turn" (Conquergood, 1989; Szerszynski et al., 2003). In this sense, food systems can be understood as complex and adaptive, often comprising non-causal relationships between action and outcomes, intent and effect (Law, 2004; Mingers, 1994). Research involving food systems transformation thus implicates "non-linear, long-term, multi-actor processes ... that are not very amenable to planning and control" (Leeuwis et al., 2021, p. 770).

In parallel, increasing calls for the decolonization of research methods have brought attention to the risks posed by work involving local and Indige- nous communities, including the often extractive nature of "outsider" collection of traditional knowledge (Levkoe et al., 2019; Smith, 2013; Steeves, 2018). This is of particular relevance for food scholarship, in which ecologically sensitive practices and embodied ways of knowing often intersect with Western methodological conventions (Bradley \& Herrera, 2016; J. T. Johnson, 2012; Ritenburg et al., 2014). Imposing such frameworks can reinforce historically problematic power relationships and privilege academic objectives over community needs and, more generally, the greater social good (Bortolin, 2011; Flicker, 2008; Kepkiewicz et al., 2019). Furthermore, questions of accuracy and relevancy may arise, given that disciplinary methods do not always account for sensory or affective experience (Montuori \& Donnelly, 2016; Todd, 2018), nor for systems that "do not hold still for their portraits" (Clifford, 1986, p. 10). In the case of food systems research, using methods that are blended and improvisational can be an effective response.

This paper presents outcomes from the TimorLeste Food Innovators Exchange project (TLFIX), a multifaceted futuring ${ }^{1}$ initiative centered on the food and foodways of Timor-Leste, including challenges to individual and collective health, as well as cultural and economic sustainability. A sovereign nation since 2002, Timor-Leste has a centurieslong history of colonial and transnational influences, which have combined to produce a complex array of effects. These include severe undernutrition and the tendency toward the "double burden of malnutrition" (undernutrition coupled with overweight) common to many industrializing and post-conflict countries (Provo et al., 2017). As well, through ongoing waves of migration and mixing, the sense of cultural identity in Timor-Leste is highly blended (Arthur, 2019), making fixed understandings of national heritage, Indigeneity, sovereignty, tradition, and language elusive. Within this context, TLFIX brought together local and outsider collaborators, worked toward diverse objectives, bridged the development, tourism, and aca-

\footnotetext{
${ }^{1}$ Futuring can be understood as the intentional "identification, creation and dissemination of images of the future, shaping the possibility space for action, thus enacting relationships between past, present, and future” (Oomen et al., 2021, pp. 2-3). In this sense, futuring acknowledges and engages with extant realities while imagining and attempting to realize better alternatives.
} 
demic sectors, and engaged with diverse knowledge paradigms. Moreover, by remaining open to emergent opportunities, the project team produced and encountered a range of outcomes both anticipated and serendipitous.

In what follows, I provide one account of this hybrid initiative, reflecting on its effects in the short and longer term. My aim is to show that a non-linear, open, and "messy" research project can be highly productive for a diverse array of stakeholders, and that outcomes from such projects may be both quantifiable and demonstrable as well as embodied and speculative. To address this range of potentialities, I take inspiration from GibsonGraham's (2014) call for "thick description and weak theory" when interpreting or imagining future possibilities, an approach relying less on "proving" established models and more on observation and interpretation that "yields to emerging knowledge" (p. S149), leaving space for reflection on potential implications. My "weak theory" includes the broad notions of recombinance, responsiveness, and relationality, which are meaningful in the context of collaborative work on and with the performativity of food systems, and which offer a way to deploy methods and paradigms that productively embrace improvisation and innovation.

\section{Recombinance, Responsiveness, and Relationality in Food Research}

In imagining sustainable food futures, Belasco (2006) proposes recombinance as an approach that eschews the "take-it-or-leave-it homogeneity" (p. 219) of technocratic "solutions" to systemic challenges, as well as fantasy efforts to return to a "simpler" pre-industrial food system. Instead, recombinance blends practices - some technoscientific, some ecological-relational-to find effective paths forward. Practical examples include urban and vertical farming, small-scale digital agriculture, and alternative protein production (Broad, 2020; Florey et al., 2020; Haberman et al., 2014). In a complementary sense drawn from genetics, recombinance also suggests that by making key changes to actors and their behaviors in the here and now, we can produce long-term ecosystem transformation in the future (Glick \& Patten, 2017). In other words, by exchanging diverse food knowledges, practices, and motivations among individuals and groups today-i.e., the "DNA" of our food systems - new traits and interactions might be produced in generations to come.

Like recombinance, the notion of responsiveness invokes grounded and improvisational methods that can lead to unexpected outcomes and "alternative social spaces of engagement and resistance" (Fischlin \& Heble, 2004, p. 2). Responsiveness is particularly valuable in food systems work that addresses both longitudinal issues and material practice, given that such contexts are performative (Callon, 1984; Mansfield, 2003; Santich, 1996; Szanto, 2018). This means putting aside conventional expectations regarding cause-and-effect relationships and adopting a non-linear-i.e., complex and adaptive-understanding (Lien \& Law, 2011; Stefanovic, et al., 2020). Dynamic subjects in food systems work demand dynamic research frameworks that are able to adapt in real time to the opportunities and outcomes that emerge.

In dialogue with and extending the concepts of recombinance and responsiveness, relational paradigms reveal the value of ecological and embodied ways of knowing, as well as alternative interactions in both time and space (Cole, 2017; Hart et al., 2017; Johnston et al., 2018; Ritenburg et al., 2014; Romm, 2020). Relationality undergirds Indigenous research methods (Wilson, 2009), while also easing frictions between local perspectives and the efforts of outsiders to understand them. In this sense, it foregrounds that knowledge is "situated" (Haraway, 1999); that is, an effect of the knowledgecreator/holder's unique positionality in the world. Acknowledging and engaging with situatedness is critical to enabling pluralistic understandings of food and food systems, particularly when such work involves people from diverse traditions of knowing and doing. Relationality necessitates engaging with the surrounding environment (ecological knowing) as well as the sensory-corporeal memories of lived experience (embodied knowing), rather than relying on pre-determined systems of measurement and validation. In the context of Western researchers working with Indigenous communities, "Two-Eyed Seeing" (Bartlett et al., 2012) has been proposed as a way to relationally navigate historic dualities and power imbalances; 
supporting collaboration among local participants and outsider researchers, "Two-Eyed Seeing" can be understood as a methodological form of recombinance, one that "facilitate[s] the "talking and walking together"” (p. 334) of different paradigms. Such an approach is crucial for cross-community food research, whether or not it falls within the patterns of Indigenous/non-Indigenous collaboration.

A valuable means of activating relationality in research is to interleave storytelling and reflection with other methods. A millennia-old practice of knowledge translation, storytelling concomitantly builds connections among documented information, embodied knowledge, research participants, and research outcomes (Boje, 2011; Dolejšová et al., 2017; L. Miller et al., 2011). It is also an effective means of redistributing power within knowledge relationships (Conquergood, 2002; Doonan, 2015). Michel de Certeau's assertion, "what the map cuts up, the story cuts across" (1984, p. 129), implicates the boundary-blurring nature of oral narrative and its capacity to link concepts, places, and times that have been otherwise divided by political forces. In the same vein, reflection and exchange, as practices that complement disciplinary methodologies, can identify points of articulation among disparately gathered data. In this text, I describe storytelling and reflection as methods deployed in TLFIX, as well as modes through which the project team came to a new understanding about the varied ontologies of storytelling itself. Storytelling and reflection also structure my own writing, inviting readers to relate to my interpretation of these events in their own way — with acceptance, reticence, curiosity, or other responses.

Together, these threads begin to outline the characteristics of TLFIX, leaving space for the project to be understood in diverse ways and paralleling the diverse outcomes that it helped create. Recombinance, responsiveness, and relationality may also provide an alternative framework in which to understand Timor-Leste itself, a place that tends to resist conventions and prevailing definitions.

\section{Project Context}

The Democratic Republic of Timor-Leste, also known as East Timor, ${ }^{2}$ became a sovereign nation in 2002, following a multi-century history of colonization, revolt, independence efforts, occupation, invasion, civil war, and ongoing violent unrest (Molnar, 2010; Siapno, 2013). Today, a range of governmental bodies are engaged in myriad nationbuilding efforts, aimed at educational, health, trade, and political goals (Leach, 2016). In parallel, many community initiatives are underway to address the multigenerational trauma that has taken place, and which has led to complex societal relationships both within Timor and with external nations (Borgerhoff, 2006). Complementing locally driven efforts, multiple international influences are also at play within Timor, including non-governmental development agencies, commercial and corporate organizations, and cultural and scholarly actors (Dunphy, 2013; C. M. Johnson, 2015; McGregor, 2007; Murta \& Willetts, 2014). While this article does not directly address the gamut of influences on the people of Timor and their movement toward political, economic, and social stability, they nonetheless inflect the ways in which TLFIX unfurled.

The Timor-Leste Food Innovators Exchange was conceived in 2017 with the aim to "reinvigorate the production and utilisation of healthy Timorese foods (both wild harvested and locally grown) to improve food security and address malnutrition" (TLFIX, 2018). Despite having exceptional biodiversity (Denis, 2014; Guillaud et al., 2013), Timor was historically less subjected to agricultural exploitation than some other colonized regions (Borgerhoff, 2006; Molnar, 2010), in part because of its mountainous terrain and minimal transportation infrastructure. Nonetheless, ongoing waves of outside influence have displaced traditional and local foods with more highly processed, transnational imports, which is correlated with the rise of several food-related health challenges (Guttal, 2009; Howe, 2013).

Recent data demonstrate that these challenges and others affect large percentages of the Timorese

\footnotetext{
${ }^{2}$ For the purposes of this text, and in keeping with the local naming habits I observed, I refer to the country either as "Timor" or "Timor-Leste," using "Timorese” as the adjectival form.
} 
population, including almost half of children experiencing chronic undernutrition and stunted physical development, and a quarter of children suffering from acute malnutrition, leading to physical wasting. Iron deficiency anemia is extensive among both children and women of reproductive age (General Directorate of Statistics, 2018; TimorLeste Ministry of Health, 2014). These realities are in part due to the fact that over forty percent of the Timor-Leste population lives below the national poverty line, but also to shifting food-consumption habits and the limited availability of nutritious, culturally appropriate food products (Andersen et al., 2013; Bonis-Profumo et al., 2019). In parallel to these health challenges, and due to both affinities for and antipathies toward food associated with Timor's historic oppressors and colonizers, there are widely varying attitudes toward traditional Timorese foods (Castro, 2013). Indeed, the notion of traditional is extremely heterogeneous in Timor, depending on the scale of history one takes.

TLFIX was an initiative of the Timor-Leste Food Lab (TLFL), a social enterprise owned and operated by Alva Lim and Mark Notaras, Australian nationals who had been working in Timor since 2011. TLFIX was funded by innovationXchange, ${ }^{3}$ a development program emerging from LAUNCH Food, ${ }^{4}$ which itself is supported by USAID and Australia's Department of Foreign Affairs and Trade (DFAT). Agora Food Studio, ${ }^{5}$ a café-restaurant headquartered in the capital city of Dili, provided a revenue stream for TLFL, while also working to regenerate local interest in and consumption of traditional Timorese food products. TLFIX, TLFL, and Agora all operate under a common strategy that merges taste and the pleasure of eating, pride and empowerment generated through commercial food provisioning and communications, and the role of diversity within nutrition and well-being.

Following several preparatory efforts in Dili, TLFIX established a multiphase pilot project, initially scoped for a duration of six months. The pilot was eventually conducted over the nine months from July 2018 to March 2019, and took place in both Dili and Ataúro, an island some 35 $\mathrm{km}$ to the north of the capital. Ataúro falls within the municipal district of Dili, and comprises six villages and a population of about 6,000 residents (Figure 1). The choice of research sites was based on the infrastructure and community provided by Agora, as well as the project instigators' existing relationships with homestay ${ }^{6}$ operators on Ataúro.

\section{Project Scope}

TLFIX was conceived within an international development framework as a pilot for a potentially more extensive effort toward achieving local empowerment, knowledge making, economic development, and social change. It brought together community and academic researchers as well as policy and development advisors. The research plan and governance model were designed to be contextually responsive; that is, as new themes and relationships emerged over the course of the initial timeline, the project team was able to modify its objectives and methods, and pursue emergent avenues for knowledge translation and dissemination.

To mitigate risks regarding the potentially extractive nature of food systems research, the TLFIX objectives were identified by Timorese advisors and community food practitioners, with the development and academic collaborators serving as "consultants" to these local "clients." The

\footnotetext{
${ }^{3}$ See https://ixc.dfat.gov.au/

${ }^{4}$ See https://www.launch.org/food/foodchallenge/

${ }^{5} \mathrm{Lim}$ and Notaras founded Agora in 2016 with the objective of training Timorese youth in food tasting, cooking, and service, as well as communication skills and peer training. Following a model of youth empowerment, the organization has built a sustainable "pipeline" of young leaders engaged in peer-to-peer education, while simultaneously valorizing the Timorese cultural practices of gastronomy and oral narrative. In early 2020, due to the COVID pandemic, Lim and Notaras returned to Australia and the Agora and TLFIX efforts were temporarily suspended. The TLFL team later re-opened Agora, however, with plans to apply the TLFIX approach toward future projects that support COVID recovery efforts. Lim and Notaras also transitioned Agora to a staff-ownership structure, retaining a mentorship role in the organization while stepping back from day-to-day operations.

${ }^{6}$ Homestays are similar to bed-and-breakfast operations, allowing private residents to offer food and accommodation to visitors to Ataúro, which otherwise has a limited range of tourism services.
} 
project budget came from a development-based initiative, itself funded by international aid organizations. My own role in the project (described below) was thus in service to the project team - a "consulting academic," rather than a scholar with his own agenda, research objectives, and funding. Together, these foundational elements helped decentralize power within the project team, facilitate negotiated decision-making processes once the project was underway, and support greater equitability in the methods deployed and outcomes realized.

Three broad efforts were brought together, following quantitative, qualitative, and materialbased approaches. Research included eater surveys, designed to uncover attitudes regarding Timorese ingredients and dishes, while also providing occasions for informal observation of local food markets and behaviors. Intergenerational storytelling brought forward memories and practices related to historic and contemporary foods and the associated habits of consumption. It also created a key moment for project team members to reflect on their own situated understandings of how storytelling itself operates. Food product development capped the process, providing opportunities for further relational exchange while creating tangible outputs that could be market tested and potentially commercialized. Together, these modalities were aimed at fulfilling the TLFIX goals of understanding, valorizing, and promoting healthful and nutritious local food, as well as helping partner communities adapt to and innovate within Timor-Leste's current food realities.

The work was carried out by a team of collaborators who themselves represent a range of localness, Indigeneity, non-Indigeneity, and outsider status. They included Timorese food and tourism practitioners, Timorese Hakka (Chinese) and

\section{Figure 1. Timor-Leste, at the Eastern Tip of the Archipelago Including Java, Bali, and Lombok, Represents an Important Intersection of Biospheres and Historic Species Migration}

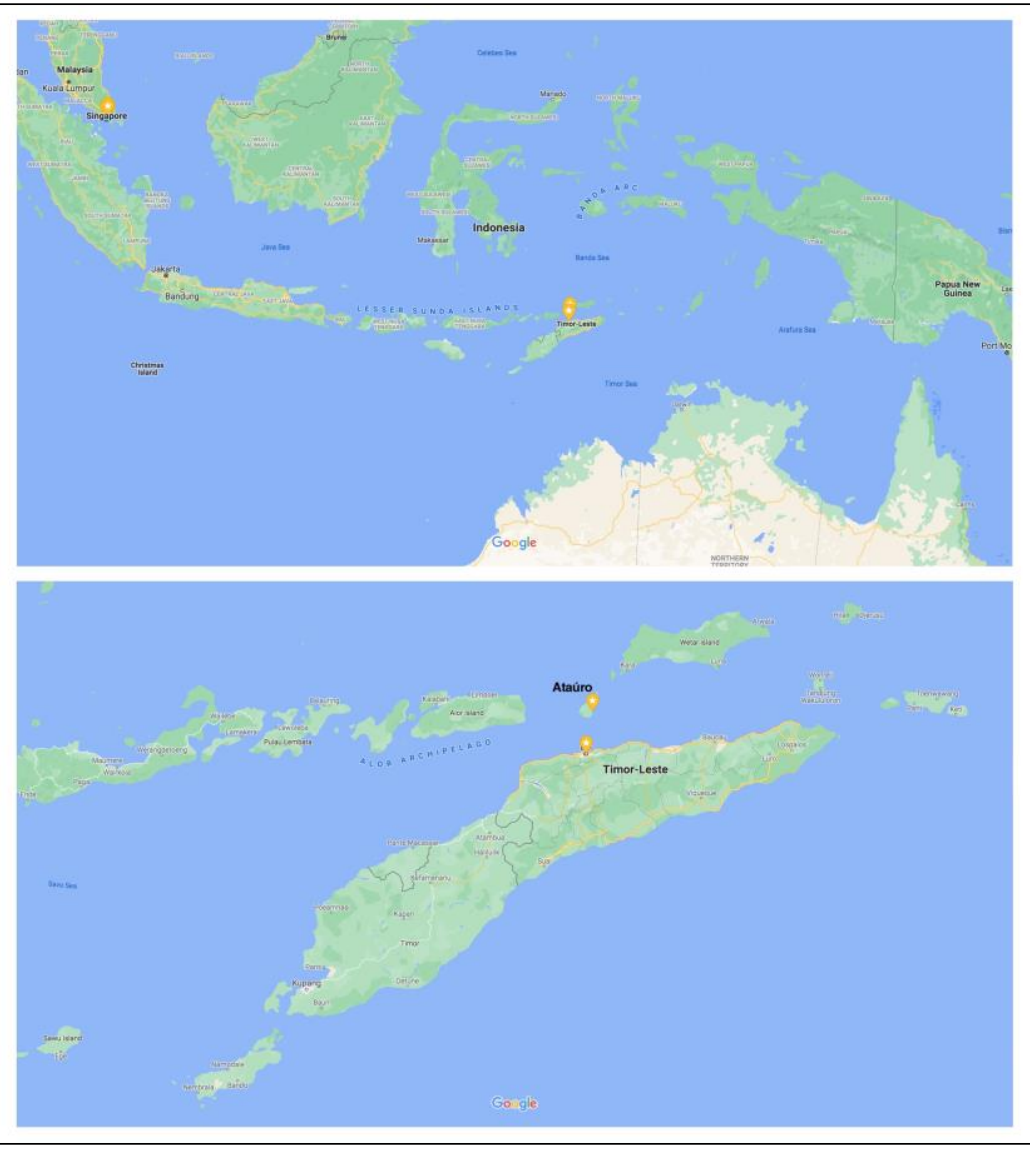

Source: Google Maps, n.d.

Timorese administrators and advisors, Australian social entrepreneurs, an Australian development worker, and a Canadian food scholar. It is important to note that while the two key instigators of TLFIX are not native to Timor, they have extensive development experience in the country, as well as strong ties to the community and a deliberate focus on serving local needs.

As the Canadian food scholar in question, I acknowledge that even as I advocate for pluralistic knowledge and mixed-models of knowledge making, I am the sole author of this paper. This was a decision made in consultation with the other team members. In producing the current text, I also consulted with them on the format and framing, and received extensive support in the form of notes, images, reflections, and data syntheses. Although not named as co-authors, their voices and experi- 
ences are represented here as faithfully as I know how. Together, we recognize our contributions as collectively and differently meaningful, whether in the context of making academic texts, nonacademic words and images, or the more tangible benefits of social change that have been generated locally in Timor.

\section{Project Objectives and Methods}

At the outset of the project, the TLFIX objectives were to improve perceptions of local food and address malnutrition in Timor-Leste through the participative development of innovative, commercialized food products. A corollary goal was to build community and policy relationships that could allow the pilot project to evolve into a longer-term effort. At the same time, it was necessary to acknowledge the intense complexity that characterizes food systems as well as the equally complex nature of 'Timor's socio-political history and contemporary foodways. Therefore, a mixed approach was taken, engaging both a development framework and a research framework. Figure 2 portrays the former, including the broader, actionresearch goal of improved sustainability and nutrition as critical components of a future Timorese food system.

The research framework that was established then drew on the identified development goals, setting specific research phases, intended interim outcomes, and the potential for emergent outcomes. (Table 1.) Broadly, the work entailed (a) two baseline surveys, one targeted at participants within the TLFIX project (members of the Ataúro and Agora communities) and one at visitors to Ataúro homestay facilities; (b) two endline surveys, targeted at the same participants; (c) qualitative observation of food species and products available at the Beloi village market and elsewhere on Ataúro; (d) intergenerational storytelling workshops with Ataúro residents, to surface and document historic and heritage foods; (e) recipe innovation and product development, based on the preceding work and followed by market testing and feedback; (f) research team reflection and debriefing, to glean additional details and observations.

The instigators of TLFIX explicitly sought to engage their Timorese collaborators in project leadership, relationally adopting local models of cultural knowledge and practice. In this respect, while the project deployed two relatively conventional frameworks, it also made space for methods, theorizations, and objectives to adapt responsively over time. This included moments when the needs and perspectives of the participants showed that a new direction should be taken.

Because one desired outcome of the pilot was to bring about long-term change at the institutional and governmental level, the team also included a policy advisor familiar with the Timor-Leste federal government. Having played a number of roles in such circles, Filipe da Costa helped align the TLFIX design — and its eventual outcomes - with the country's long-term policy planning and food strategy development. As an advisor to the prime minister and to the National Council for Food Security, Sovereignty and Nutrition in Timor-Leste (KONSSANTIL), da Costa was also wellpositioned to disseminate outcomes from the project within government and civil society circles. ${ }^{7}$

Consistent with its community focus, TLFIX also involved several homestay operators from the Ataúro Homestay Association (AHA). Members of AHA had approached Agora in February 2018, requesting assistance with developing foods for their guests that would be more appealing to an international clientele. Specifically, the operators wanted to incorporate higher-quality ingredients into dishes that visitors would find both palatable and representative of the locale. Embedded in this request were several issues, including the availability of food products on Ataúro, the culinary skills of the operators, the perceived tastes and preferences of homestay visitors, as well an underlying tension between pride and shame in Timorese cuisine. This last derives from the country's complex colonial and conflict-laden history, leading to a very diverse spectrum of affinity for international cuisines, including those of neighboring Indonesia and Malaysia.

\footnotetext{
${ }^{7}$ In October 2019, da Costa was named to the position of Special Representative for the Timor-Leste Food Security and Nutrition Program, reporting to the prime ministerial cabinet (Pereira, 2019).
} 


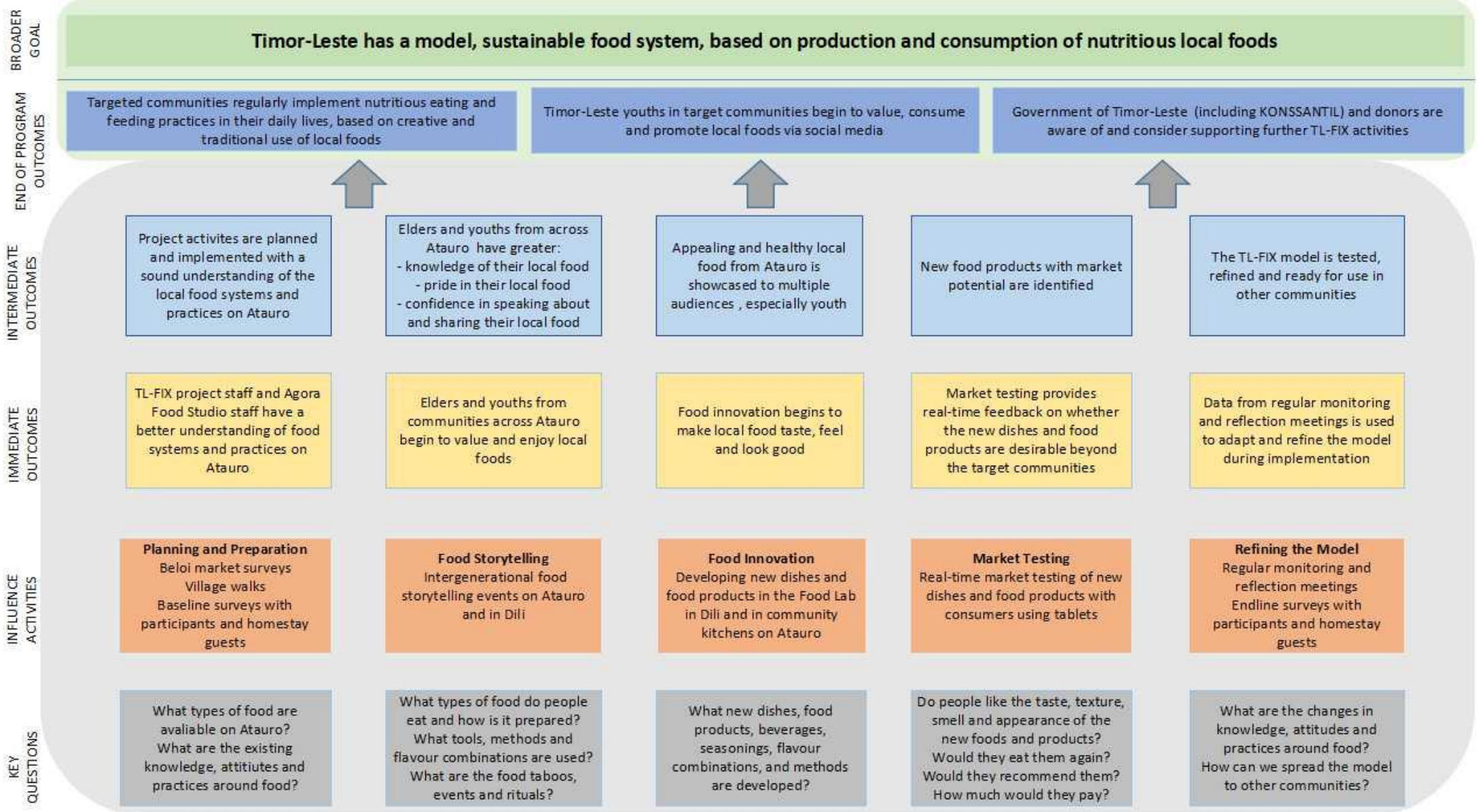

Source: Graphic developed by Luke Simmons. 
Continuous special attention was paid to interpersonal dynamics, through both project-focused discussions and more casual social interaction. This involved one-on-one conversations between team leads and other participants, focused on research methods, project management, and communications techniques, and implicated the nurturing of relationships across the team, including participation by the community members in the storytelling and food innovation phases. It is apt that many of these exchanges involved the making and sharing of meals, which foregrounded generosity and commonality, while grounding the project team in the diversity and sensory pleasure of local food. Along with our insider/outsider "talking and walking together," we spent a lot of time talking and eating together, bringing reasoned understanding of the project into relation with more ecological and embodied knowing.

Figure 3 depicts the formal relationships within

Figure 3. The TLFIX Organigram

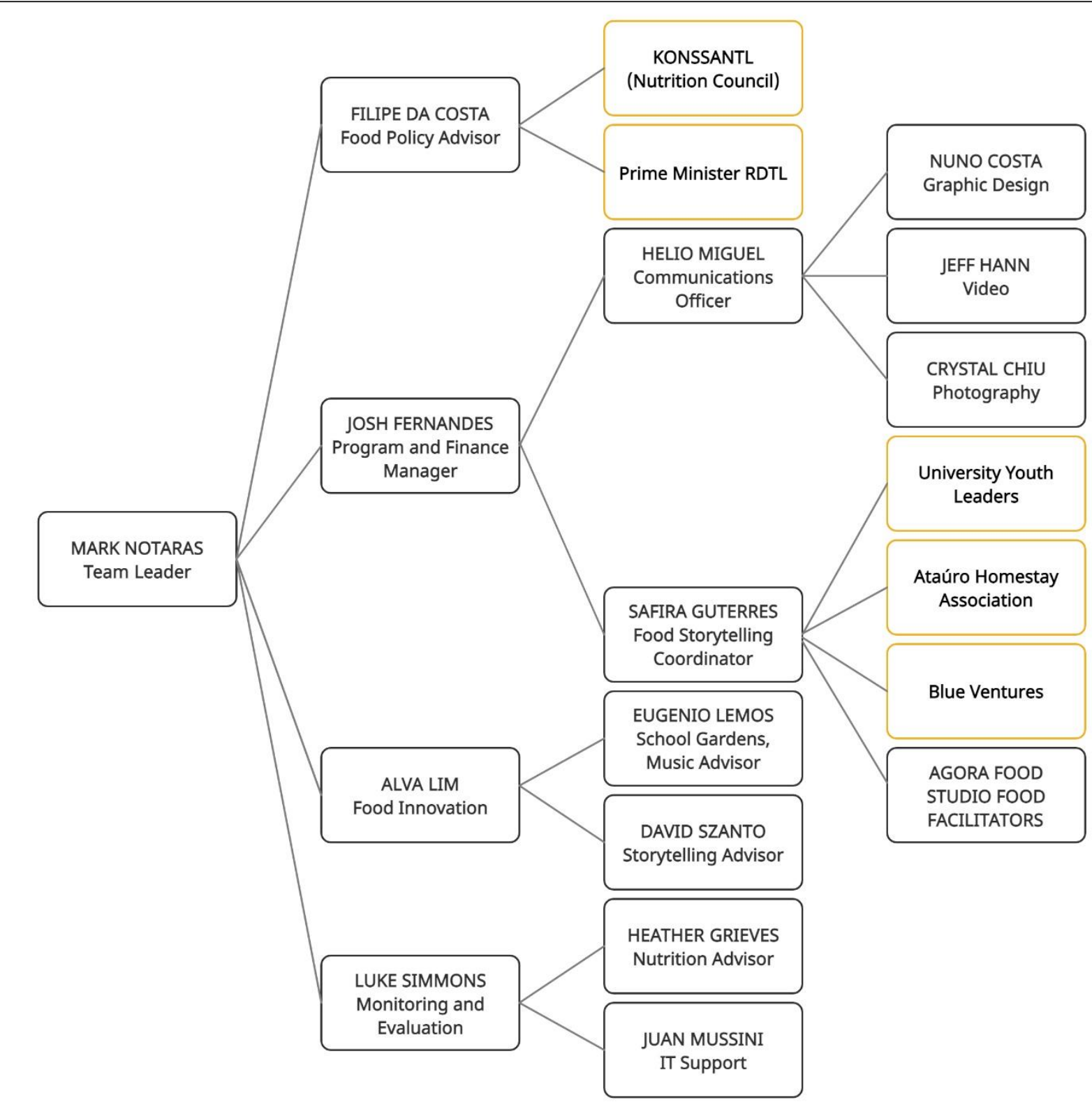


the TLFIX team, including community members, civil and governmental organizations, development actors, policy insiders, and researchers. The informal relationships are far less easily represented in graphic form.

The team's diversity was enhanced by fluidity within our designated roles, enabling each of us to respond to new opportunities as they arose. For example, through my own exposure to Indigenousdriven research in Canada, my role broadened to include coaching the team on relational methods and non-Western frameworks of knowledge. My interest in translation informed the ways in which language was used in the project-in storytelling, surveys, and various reports-and my access to academic journals prompted the writing of this article.

A notable example of our fluid role-shifting involved the negotiated process of creating the eater surveys. Four members of the team participated in this process. We translated questions into Tetun, one of Timor's two official languages, then retranslated them back into English, in order to check potential variations in meaning and reflect on more locally relevant phrasings as needed. The sociology background of our monitoring and evaluation advisor (Luke Simmons) thus encountered my food-and-communications framework and the multilingualism and local knowledge of our operations manager (Josh Fernandes). TLFIX instigator Mark Notaras brought his development-world perspective into play, as well as an outsider-insider curiosity about Timorese food and traditions. This back-and-forth process served as a model for later phases of the project, while also providing the primary interviewer (Josh) with greater capacity to probe for detail, pose questions differently, and interpret respondents' non-verbal responses. Other challenges arose regarding the meaning of some of our translated terms, including "food," in the senses of edible matter, culture, and systems, and "storytelling," which in Tetun translates to konta istoria, a term laden with both sadness and superstition. (See "Storytelling as Empowerment?" below.)

Ultimately, TLFIX became a nine-month pilot project conducted with and within several spheres of Timorese society, providing numerous occasions for such relational exchange. Other occasions arose as well, in which logistics, local politics, and participant availability created resistances that demanded responsiveness within the research process. Our approach allowed us to shift the timing of some phases, while adding or removing others. It also meant that we were able to let go of preconceived notions about what "success" should look like within the project, freeing us to accept emergence within both our methods and outcomes.

\section{Outcomes and Discussion}

As shown in Table 1, some of the project outcomes were generated by pre-planned forms of data collection and processing. But it also became clear that some aspects of the project-not formally conceived as research methods-had also generated important outcomes, particularly in the form of embodied knowledge and individual transformation. These included negotiation during project management and survey design, exchange during sensory experiences (e.g., cooking, eating, market walks), and ongoing group reflection. In what follows, I present some of the outcomes from our more formal efforts, as well as two other phases of work, during which we collectively synthesized what was taking place. These constituted a key role in re-centering community-actionable outcomes as a primary objective.

\section{Shifting Research, Shifting Objectives}

Initially, the baseline and endline surveys were aimed at understanding local and outsider attitudes toward Timorese ingredients and cuisine, including their perceived nutritional content and pleasure quotient. These surveys generated minimal results on the part of homestay guests, largely due to a lack of tourism during this period. For the homestay operators (and to a lesser extent the TLFIX team members), the survey results were more robust. They point to a shift in attitudes toward Timorese food, as well as signs of longer-term transformation among those cooking and serving local food to homestay guests. Overall, nearly all of the ten respondents reported a high regard for Timorese food, ranking it as "good" or "very good" (the top two indicators of quality).

Moreover, following the hands-on food innovation workshops, participants reported increased 
confidence in talking about Timorese food (and food in general), pride in local food, and culinary skills and knowledge. One participant, Meriam Soares, stated, "After participating in TLFIX I am cooking with nu'u tein [shredded, lightly caramelized coconut] and starting to eat corn again. We're also eating a lot more bitter foods at home again, [as well as] tamarind seed powder with honey, and millet with wild beans. In the future, I plan to run a mini local food innovation restaurant in Ataúro."

Of key importance was the dominant attitude among homestay operators that Timorese food was

Table 1. The Research Framework Initially Established for TLFIX Pilot Project (Columns 1, 2, and 3), and Some of the Unanticipated Effects that Emerged (Column 4)

\begin{tabular}{|c|c|c|c|}
\hline Research Phase & Participants & Format & Emergent Effects \\
\hline $\begin{array}{l}\text { Baseline survey of } \\
\text { TLFIX participants }\end{array}$ & $\begin{array}{l}\text { Ataúro community } \\
\text { members; Agora } \\
\text { Food Studio staff }\end{array}$ & $\begin{array}{l}\text { Structured qualitative interviews with partici- } \\
\text { pants at the start of the project to gauge their } \\
\text { knowledge, attitudes, and practices around } \\
\text { healthful local food }\end{array}$ & \multirow{2}{*}{$\begin{array}{l}\text { - Negotiated and shared understanding of } \\
\text { linguistic translation (English to Tetun and } \\
\text { Tetun to English) } \\
\text { - Increased capacity and confidence of } \\
\text { interviewer; development of technical skills } \\
\text { (use of tablet for interview process) }\end{array}$} \\
\hline $\begin{array}{l}\text { Baseline survey of } \\
\text { Ataúro homestay } \\
\text { guests }\end{array}$ & $\begin{array}{l}\text { Short-term and } \\
\text { long-term } \\
\text { homestay guests }\end{array}$ & $\begin{array}{l}\text { Online survey completed independently by } \\
\text { participants, addressing the foods eaten, and } \\
\text { the context of eating, during their homestay } \\
\text { visit }\end{array}$ & \\
\hline $\begin{array}{l}\text { Beloi village } \\
\text { market survey }\end{array}$ & TLFIX team & $\begin{array}{l}\text { Qualitative and quantitative data on foods } \\
\text { available for sale, including seasonal varia- } \\
\text { bility and apparent provenance (local or from } \\
\text { Dili/elsewhere) }\end{array}$ & $\begin{array}{l}\text { Development of relationships with local } \\
\text { market sellers and village elders, } \\
\text { supporting eventual storytelling and } \\
\text { culinary workshop with youth }\end{array}$ \\
\hline $\begin{array}{l}\text { Ataúro village } \\
\text { walks }\end{array}$ & $\begin{array}{l}\text { TLFIX team and } \\
\text { Ataúro community } \\
\text { members }\end{array}$ & $\begin{array}{l}\text { Qualitative data on plant foods and animals } \\
\text { raised in Ataúro villages, as well as wild/ } \\
\text { foraged foods gathered by villagers }\end{array}$ & $\begin{array}{l}\text { - Observation of local cooking infrastructure } \\
\text { and village layout, leading to increased } \\
\text { understanding of mealtime habits and } \\
\text { commensality }\end{array}$ \\
\hline $\begin{array}{l}\text { Intergenerational } \\
\text { food storytelling }\end{array}$ & $\begin{array}{l}\text { Meriam Soares, } \\
\text { Rogerio Soares, } \\
\text { Eu Branco, Dina } \\
\text { Martins, Felizada } \\
\text { David de Araujo, } \\
\text { Francisca Martins }\end{array}$ & $\begin{array}{l}\text { Audio documentation of storyteller narratives; } \\
\text { photographic documentation of food products } \\
\text { and names; textual documentation of food } \\
\text { names and usages; group reflection and } \\
\text { documentation of key points }\end{array}$ & $\begin{array}{l}\text { - Identification of translation problems } \\
\text { inherent to the term konta istoria } \\
\text { - Empowerment of youth research team } \\
\text { member toward deeper project } \\
\text { involvement }\end{array}$ \\
\hline $\begin{array}{l}\text { Timor-Leste Food } \\
\text { Lab and } \\
\text { Community } \\
\text { Kitchens }\end{array}$ & $\begin{array}{l}\text { Kelo Gomes, } \\
\text { Safira Guterres, } \\
\text { Alva Lim, Lucia } \\
\text { Fernandes, } \\
\text { Meriam Soares, } \\
\text { Dina Martins }\end{array}$ & $\begin{array}{l}\text { Culinary innovation, tasting, discussion, } \\
\text { reflection, and documentation of preparations }\end{array}$ & $\begin{array}{l}\text { - Grounding of the necessity of pleasure for } \\
\text { supporting increased food security and } \\
\text { improved nutrition }\end{array}$ \\
\hline $\begin{array}{l}\text { Real-time market } \\
\text { testing of new } \\
\text { preparations and } \\
\text { ideas }\end{array}$ & $\begin{array}{l}\text { Timorese } \\
\text { government } \\
\text { officials; DFAT } \\
\text { representatives }\end{array}$ & $\begin{array}{l}\text { Digital survey completed using tablet-based } \\
\text { app, facilitated by research team members }\end{array}$ & $\begin{array}{l}\text { Replacement of market testing with other } \\
\text { opportunities (collaborative dinner for } \\
\text { prime minister and other officials; media } \\
\text { appearances) }\end{array}$ \\
\hline $\begin{array}{l}\text { Team reflection } \\
\text { meetings }\end{array}$ & TLFIX team & $\begin{array}{l}\text { Monthly debriefing and documentation } \\
\text { sessions held among TLFIX team members, } \\
\text { with notes distributed to all members by email }\end{array}$ & $\begin{array}{l}\text { - Sharing of power; valorization of the mixed } \\
\text { perspectives of Indigenous and non- } \\
\text { Indigenous team members }\end{array}$ \\
\hline $\begin{array}{l}\text { Endline survey of } \\
\text { TLFIX participants }\end{array}$ & $\begin{array}{l}\text { Ataúro community } \\
\text { members; Agora } \\
\text { Food Studio staff }\end{array}$ & $\begin{array}{l}\text { Structured qualitative interviews with } \\
\text { participants at the end of the project to gauge } \\
\text { changes in their knowledge, attitudes, and } \\
\text { practices around healthful local food }\end{array}$ & \multirow{2}{*}{$\begin{array}{l}\text { - Engagement of entire Agora team in TLFIX } \\
\text { and exposure to the methods and } \\
\text { outcomes, leading to future spin-off } \\
\text { projects } \\
\text { - Increased understanding of Ataúro } \\
\text { community dynamics, including } \\
\text { relationships among homestay association } \\
\text { members and other tourism operators }\end{array}$} \\
\hline $\begin{array}{l}\text { Endline survey of } \\
\text { homestay guests }\end{array}$ & $\begin{array}{l}\text { Short-term and } \\
\text { long-term } \\
\text { homestay guests }\end{array}$ & $\begin{array}{l}\text { Online survey completed by participants, } \\
\text { following same structure as baseline survey, } \\
\text { to gauge change over the course of the } \\
\text { project }\end{array}$ & \\
\hline $\begin{array}{l}\text { Communications } \\
\text { and outreach }\end{array}$ & Core team & $\begin{array}{l}\text { Development of video channel (Facebook and } \\
\text { YouTube); endline report to funders, in } \\
\text { support of future, longer-term project; blog } \\
\text { posts and scholarly articles; photo library; } \\
\text { Facebook food innovation challenge }\end{array}$ & $\begin{array}{l}\text { - Media appearances (TV, online) by project } \\
\text { director and policy advisor } \\
\text { - Engagement of } 200 \text { University of Dili } \\
\text { students in TLFIX objectives }\end{array}$ \\
\hline
\end{tabular}


good, nutritious, and distinctive, and that they would embrace being advocates for it in the future. Several operators, who are exclusively women, also noted that their children and their husbands had become more interested in cooking, and were now participating in that aspect of the homestay businesses. Initially involved for primarily administrative reasons, the Biqueli village chief, Daniel Martins, also became engaged with the importance of these outcomes for the longer-term physical and cultural health of his community: "I like the idea of rediscovering the abandoned nutritious foods, and bringing together community from different villages to exchange knowledge and experience regarding local foods. It reminds the youth of our healthy, heritage ingredients, which have nourished our ancestors."

In addition to the reduction in scope of the survey data, the team did not ultimately carry out the post-workshop market testing of commercializable products. Although the development of new foods would eventually take place, three new foci had emerged as more pressing project objectives: (a) increasing pride and confidence among homestay operators (as described above); (b) empowering youth participants, through research skills acquisition and gastronomic entrepreneurialism (see below); (c) disseminating project outcomes within media and political spheres (see below).

Rather than resisting the shifting nature of our research context by attempting to remediate the lack of survey data with follow-up efforts or forge on with market testing of products, the team recognized the need to respond to what was emerging before us. Following the model that improvisation theory puts forward - accept, agree to, and build on dynamic change-we chose to follow the emergent opportunities that arose. These shifts illustrate the real-time, responsive character of the project design. Moreover, because of the outcomes that were eventually realized, the value of being responsive to non-linear food system relationships was underscored.

\section{Storytelling as Empowerment?}

Initially, the storytelling workshops on Ataúro (at the Manukoko Rek homestay in Vila, and later in
Biqueli village) aimed at two primary outcomes. The first was to surface examples of local foods through the recollection of past ingredients and dishes. For the Vila workshop, participants brought numerous food items with them, serving as both illustrations and tasting samples. The project team also provided food (coffee, roasted kumbili, pickled bilimbi, and several types of fruit), both as a gesture of hospitality and as examples of what we ourselves found delectable within Timorese food. The mutual exchange of edibles supported our relational research paradigm and was intended to demonstrate our own embodied pleasure and understanding.

Team members who were more fluent in Tetun documented the food items in words and images, as well as the stories to which they were attached. These included narratives about cultivation, processing, cooking, and eating. In combination with the results of the market observations, this generated an extensive summary of food items that historically had been eaten and either abandoned or maintained within the local diet. The narratives were rich in detail, demonstrating a mixed set of attitudes toward local food, ranging from pride to dubiousness, as well as confusion about why one food might have fallen out of favor despite its former appreciation. Table 2 depicts some of these foods, including their Tetun names and English meaning. I consider the details summarized to be both true and subjective, meaningful and non-exhaustive- a compendium of highly relational, situated knowledge.

The second aim of the storytelling process was to engender pride and confidence in local food, both through the enactment of memory and the potential for futuring that oral narrative can produce. This framing drew on my long-held interpretation of storytelling as an empowering process, one that can rearrange the "truth" of historical records, which are often produced by those in dominant positions of power and privilege. By recalling and expressing multiple, individual accounts of the past, the official account may be challenged and, in some cases, refigured so as to allow alternate understandings of history to emerge.

Those recounting stories in Vila were all native Timorese, speaking Tetun and the dialects of their 
Table 2. Some of the Foods Shared During the Oral Narrative Event at Manukoko Rek in Vila, on Ataúro

\begin{tabular}{ll}
\hline koto moruk & wild bitter beans \\
- Processing to remove toxins requires up to twelve cycles of boiling and/or soaking and \\
boiling; each Timorese community has their own method, specific to the microclimate \\
and bean composition. \\
- Once processed, the beans are called koto tisi, indicating that they are ready to be \\
eaten plain or seasoned (e.g., stir-fried with chili and garlic) and eaten as a snack.
\end{tabular}

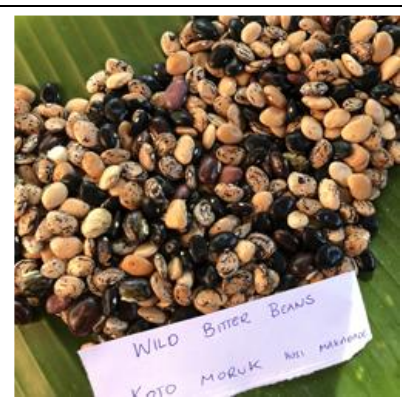

lehe velvet beans

- Also known as monkey tamarind or cowage, processing lehe includes soaking and boiling to first remove the outer pod and then more boiling and water replenishment to remove the bitter compounds that are naturally present.

- Once the taste becomes "sweet," lehe are traditionally eaten with coffee.

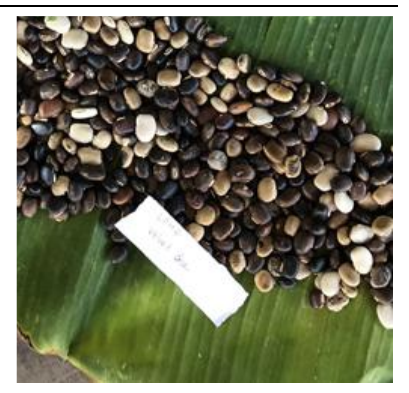

nu'u tein shredded and lightly caramelized coconut flesh

- A by-product of making coconut oil, nu'u tein is sold at low-cost in baggies, or in bulk as shown here.

- It is somewhat comparable in taste and texture to crumbled brownie.

budu tasi seaweed-and-sago (palm starch) crackers

kripik - Similar to prawn crackers, budu tasi kripik are made without animal products.

- Deep-fried in coconut oil, the crackers puff up and take on a pleasant, somewhat fishy taste.
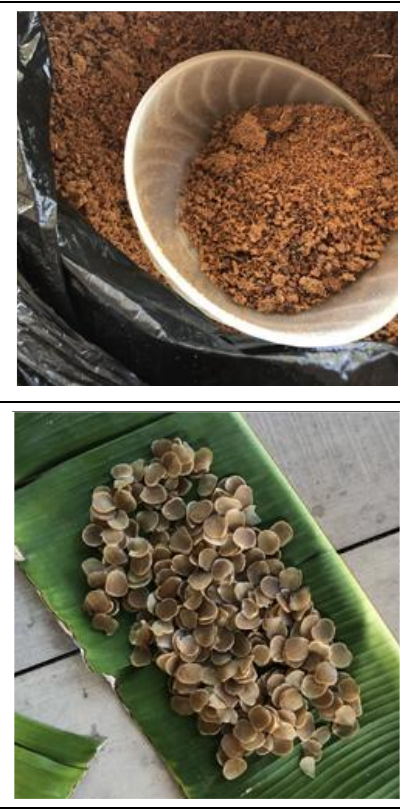

marungi moringa

- Named as a "superfood" globally, moringa contains significant protein and vitamin content.

- A foraged food widely available on Ataúro, it is considered a staple of almost all meals.

- A simple soup made of moringa and fatuk masin (black sea rocks, see below) is considered both sustaining and restorative of health.

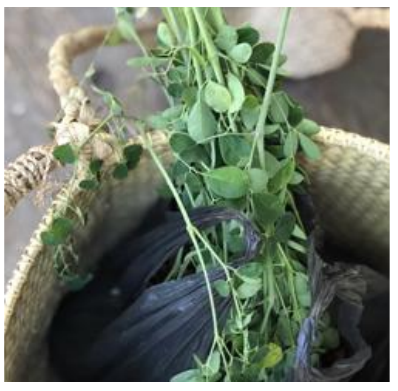

continued 
fatuk masin black sea rocks

- Rich in mineral salts, the rocks are used as a flavoring agent and nutritional additive to a simple soup made with moringa.

- The rocks can be boiled and reused many times.

batar no corn and pigeon peas

tunis - Corn kernels are soaked before pounding, which allows them to be softened and reduced to consistent sizes that are neither powdery nor chunky, improving the mouthfeel when cooked.

- Pigeon peas are cooked together with parboiled, pounded corn, to which moringa, pumpkin leaves, and bilimbi pickle (see below) may be added for a traditional, typical Timorese stew.
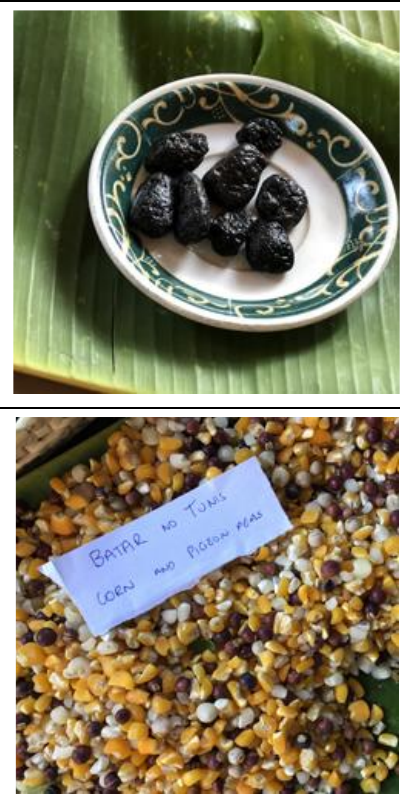

sukaer tamarind seed powder

musan u'ut - Once the tamarind pulp is removed from its pod, the seeds are sun-dried and then dry-fried until crisp, after which they are pounded to remove the skin of the seed.

- Processed seeds are then soaked in water and eaten as is, or pounded into a powder that may be eaten with honey.

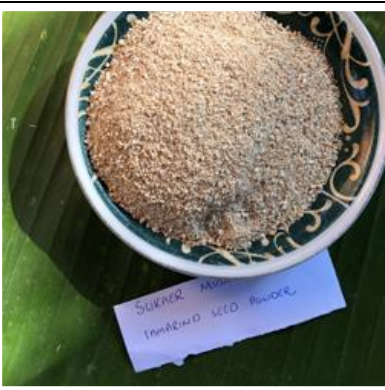

kumbili giant lesser yam

- A foraged tuber that is pit-roasted onsite, in the hills where it is found, kumbili has a fluffy, striated texture and a toasty, slightly sweet, bread-like taste.

- The roasting process reduces the yam's water weight and thereby the labor necessary to transport it to village markets.

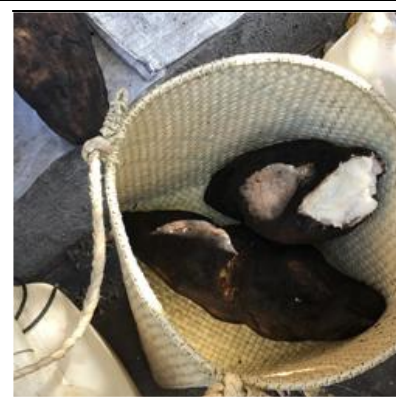

bilimbi bilimbi

- Also known as cucumber tree or tree sorrel, bilimbi is similar to star fruit and contains high concentrations of oxalates, which can be beneficial in small doses and potentially harmful when consumed excessively.

- Bilimbi forms the base of one of many forms of budu, a generic Tetun term for highly flavored, fermented condiments.

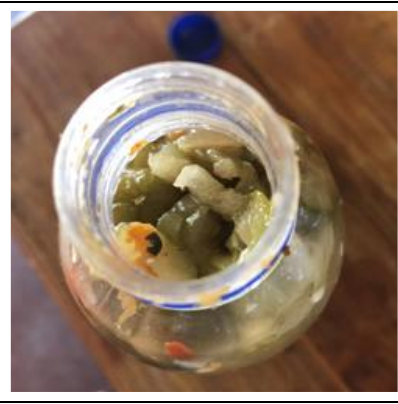

Photos by Crystal Chiu 
own communities, but not English. Over the course of this session, some participants expressed hesitation or discomfort about what they were being asked to do. While the narratives eventually unfurled in generous and informative detail, we came to understand that the initial resistance was related to our well-intentioned but partially uninformed understanding of konta istoria, the Tetun term we were using to mean "storytelling." Through later debriefing and reflection sessions, we came to realize that a more nuanced interpretation of konta istoria is "to correctly recall facts from the past." Rather than being understood as a mode of imagining an empowering future, konta istoria carries a different weight of responsibility in Timor. Those who practice it are considered record keepers, community members who embody the knowledge of family relationships, historic events, and financial debt. Moreover, many Timorese believe that to recount past events may enable them to be reproduced in the future. For a country whose past decades are characterized by extreme violence, oppression, and loss, konta istoria can be fraught - a painful and risky process, rather than one that is celebrational or creatively empowering.

In translating storytelling into konta istoria, we neglected to recognize the ways in which the Tetun term carries an emotional and historically laden meaning. However, as our reflection sessions continued, we arrived at the notion of "weaving" as a more apt motif for what we wanted to communicate. Timorese culture, like that of other nations in the region, places high value on woven textiles, both from artistic and economic perspectives. Tais are handwoven cloths that serve a number of purposes in Timorese society. Both functional and decorative, tais are often meticulously detailed, using traditional techniques such as hand-dyeing. They are worn for ceremonial and special occasions, and the patterns and images woven into them signify important events in family histories. Notably, because they are so time- and skillintensive, they also represent wealth, and are seen as an investment in the family's future (Barrkman, 2014). The making and sharing of tais thus embodies more directly the empowerment and futuring that we had intended to invoke with "storytelling." As we moved forward, therefore, we dialed back our use of konta istoria and instead suggested to our participants that their narratives were a kind of weaving together of future foodways.

This subtle but critical realization was a powerful check on our collective outsider perspective, and is in many ways a keystone of this paper. It is a metonym for the ways in which epistemologies are not always translatable, as well as reinforcement for deploying research paradigms that are heterogeneous and relational. For TLFIX, however, it was also an important turning point for adjusting the project's subsequent phases.

Having involved elders, adults, and youth in the oral narrative event at Manukoko Rek in Vila

\section{Figure 4. The Oral Narrative Event at Manukoko Rek in Vila, on Ataúro}

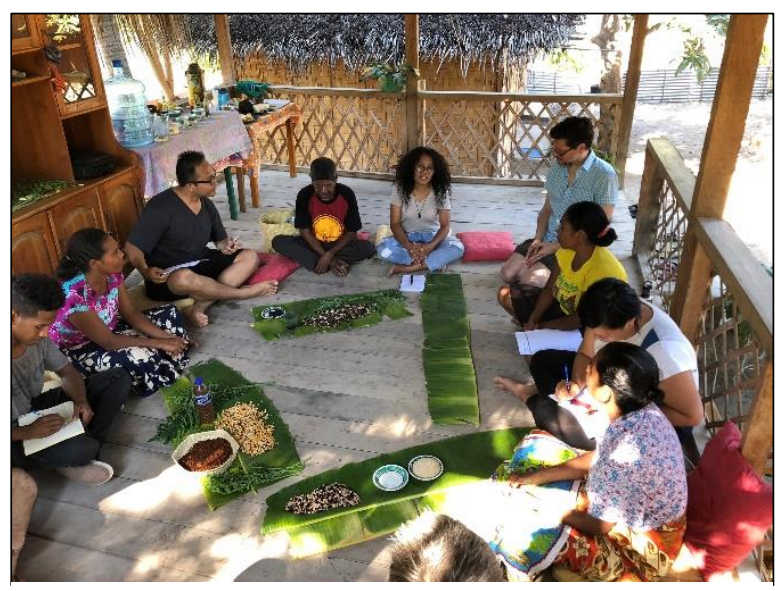

Photo by Crystal Chiu.

\section{Figure 5. The Biqueli Village Oral Narrative Event}

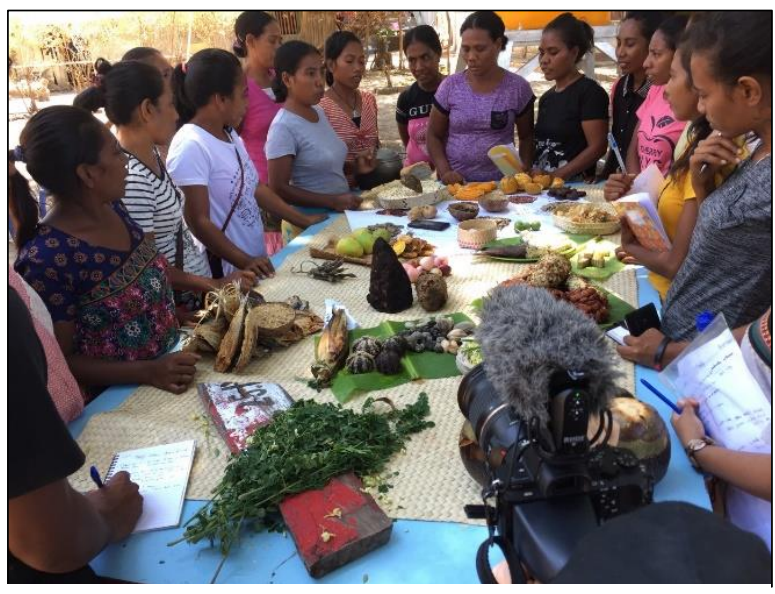

Photo by Jeff Hann. 
(Figure 4), the project team became aware of the value of actively engaging young people in food innovation and communications. Originally, we had intended to use the stories and food products as "raw material" for an eventual culinary innovation workshop. In response to the energy demonstrated for youth engagement, however, a second intergenerational community gathering was organized. Again, by taking a relational and responsive approach, the team was able to elicit opportunities and outcomes that would not otherwise have existed. The second event took place in Biqueli village on Ataúro, approximately one month after the Vila event (Figure 5). The program included food stories and tastings, as well as performances by Ego Lemos, a local musician and celebrity whose work also includes permaculture, curriculum development, and food activism. From this moment of intergenerational sharing, several community leaders stepped forward with the desire to participate in further workshops.

\section{Recombinant Foodways}

The original TLFIX scoping had included a set of culinary innovation workshops and consumeroriented market testing sessions, intended to develop commercializable food products based on the Ataúro eater surveys, market observations, and storytelling sessions. However, due to Timor's political deadlock and economic stagnation in this period, that phase of the work became untenable. Two other opportunities emerged, however, enabling the project team to reimagine the culinary component of the project. Both illustrate what recombinance might offer as a framework for future projects, because of the ways in which they bring together multiple intentions and outcomes related to the holistic nature of food.

Contemporary Timorese food culture emphasizes rice as a staple grain. Although white rice was introduced before the Indonesian occupation, its elevated status has substantially grown in recent decades, so much so that farmers will sell their own red and black rice crops to purchase it. Corn, a Portuguese colonial holdover, and the more historic millet and sorghum have been largely supplanted. The most recently adopted grain is wheat, often imported in the form of industrial baked goods and instant cup noodles-locally known as super mie. These two highly processed foods occupy the hearts and stomachs of the Timorese people, being both sensorially pleasing and symbols of the post-occupation era in which transnational products are increasingly present in the market. Youth, in particular, consume super mie in vast quantities, troubling for its impact on both human and environmental health (Adejuwon et al., 2020; Wilcove \& Koh, 2010).

In the first opportunity, the Timorese culinary staff at Agora Food Studio organized a workshop to experiment with alternate forms of both bread and noodles. The two foods were identified by the AHA members, who were asked, following the storytelling workshops, what they would like to learn to make. This very straightforward approach typified what had become the TLFIX ethos: redirect efforts toward the needs of local stakeholders.

The culinary workshop took place in collaboration with some AHA members, including Meriam Soares, who had self-selected following the Ataúro events. Agora's lead baker, Julio da Cunha, chose to riff on Mark Notaras's Greek heritage and helped the team develop several types of pita-like flatbread. Rather than making a wheat-only dough, he incorporated purple sweet potato-a native variety-as well as puréed pumpkin squash. These ingredients are both nutritious and locally produced in different growing seasons, and were thus considered practical alternates; whichever is available, the bread maintains its seasonality and relevance. Both types of flatbread were served to Agora customers, with feedback actively solicited. The responses were almost unanimously positive, and so while formalized and quantitative market testing was not conducted, the team considered both new breads to be successful outcomes. The sweet potato bread, in particular, was adopted by several AHA operators, for the relatively simple production method and ingredient availability, as well as for the spectacular taste and pinkish-purple hue. It was also retailed at four supermarkets in Dili.

Of particular note was the noodle-making workshop, during which three varieties of fresh and dried mie were developed by Julio da Cunha and his colleagues. Incorporating moringa, pump- 
kin, and sweet potato, and avoiding the problematic palm oil present in instant ramen, these quick-cooking noodles contain notably high degrees of protein as well as Vitamins $\mathrm{B}_{1}, \mathrm{~B}_{2}$, and A, calcium, and iron (Figure 6). Again served to Agora customers, "Timor Mie" was extremely popular, prompting the kitchen to prepare the noodles for both on-site eating and in dried and packaged form for preparation at home. Timor Mie has also been commercialized for supermarket sales. Notably, in 2020, the United Nations Development Programme placed an order for 10,000 packets of Timor Mie, which were distributed as part of their COVID-related humanitarian support packages. ${ }^{8}$

After the TLFIX pilot wrapped up, members of the Agora team participated in the first annual Youth Co:Lab Timor-Leste National Youth Forum on Leadership, Innovation and Entrepreneurship, in December 2019. Founded in 2017 by the United Nations Development Programme (UNDP, 2019), the program "aims to establish a common agenda for countries in the Asia-Pacific region to empower and invest in youth, so that they can accelerate the implementation of the [UN's] Sustainable Development Goals (SDGs) through leadership, social innovation and entrepreneurship" (Youth Co-Lab, 2020). The Timor Mie team won first prize, receiving US $\$ 1,500$ in seed funding to continue to develop the product and travel arrangements to Kuala Lumpur to compete at the 2020 Youth Co:Lab Summit in Malaysia. ${ }^{?}$

Even more than the flatbread, the noodles were an exemplar of recombinance. Their blending of local ingredients with transnational taste demonstrates how Timorese heritage and present-day commercial realities can create a new, hybrid result. They symbolize a food future in which pleasure, health, and environmental-economic sustainability are united, rather than at odds. As AHA operator and TLFIX participant Mispa da Costa stated, "My favorite part from the TLFIX program is transforming local foods to innovative foods."
A second experiment in recombinance took place in February 2019, representing a key moment in which research, outcomes, and knowledge dissemination coalesced. Through their relationship with LAUNCH Food (the global innovation program that funded TLFIX), Alva Lim and Mark Notaras invited New Zealand chef Robert Oliver to Dili to encounter Timorese cuisine and learn about the TLFIX outcomes. In collaboration with Oliver, the AHA operators, led by Meriam Soares, developed a "Flavours of Ataúro" tasting dinner, which was prepared and formally served to the Timor-Leste Prime Minister, key ambassadors, and members of the National Nutrition Council. The dinner was extensively covered by national media outlets, and received high praise from the Prime Minister. The country's digital television channel, GMNTV, featured interviews with TLFIX policy advisor Filipe da Costa and team lead Mark Notaras, and covered Oliver's visit and the meal preparation itself.

Propelled by the media coverage, two additional outreach events were organized during Oliver's visit. The first featured Oliver and da Costa, discussing the nutritional and sensorial value of local foods in Timor and the South Pacific. It was attended by more than 200 University of Dili (UNDIL) students, enrolled in the school's medicine and public health program. The second event, held in response to demand from the UNDIL students, took the form of a food innovation session coordinated by TLFIX, effectively extending the previous youth-engagement workshops and furthering the project objectives.

The impact of the Flavours meal went on to produce outcomes over the following months, including social media pick-up and traffic directed to the TLFIX YouTube channel. ${ }^{10}$ This space, designed as a component of the project communications, represents both an archive of the Agora and TLFIX initiatives, as well as a knowledge transfer and translation tool for ongoing youth engagement.

Two youth members of the team continue to

\footnotetext{
${ }^{8}$ This put approximately US $\$ 20,000$ into the local economy, money that otherwise would have been used to import non-Timorese food into the country.

${ }^{9}$ The Kuala Lumpur summit was eventually cancelled due to the COVID pandemic.

${ }^{10}$ https://www.youtube.com/channel/UC5x7Hk5uYLaLgQ6ExmlWxQw/videos
} 
experience transformative outcomes, suggesting that at least some of the "food systems DNA" of Timor has evolved. Storytelling coordinator Safira Gutérres, through mentorship and support from team member Luke Simmons, applied to and received an Australia Awards Scholarship, funded through the Department of Foreign Affairs and Trade. At the time of this writing, Gutérres was enrolled in a four-year nutrition science program. Program and finance manager Josh Fernandes, through the negotiated process of developing and deploying the research surveys, acquired new field research skills and a self-reported increase in confidence in his current work. Coached by Filipe da Costa, and motivated by his experience with TLFIX, Fernandes also applied for and received US $\$ 15,000$ in start-up funding for his own food survey project. He initiated the network, AHI (Gathering Food Innovators), to conduct food research in remote areas of Timor, following the TLFIX model and collaborating with members of the Agora team. Both outcomes-as well as the future outcomes that Gutérres and Fernandes will no doubt generate- can be attributed to the embodied learning that TLFIX enabled, and further suggest the value of using recombinance as an interpretive framework. ${ }^{11}$

For their part, Mark Notaras and Alva Lim chose to evolve Agora's day-to-day operations as a public-facing food outlet, and redirected resources to focus on youth training and delivering consulting services. This included occasional offsite catering services and other non-restaurant food provision, providing occasions for both practice-based

Figure 6. Three Varieties of Timor Mie and Their Nutritional Content

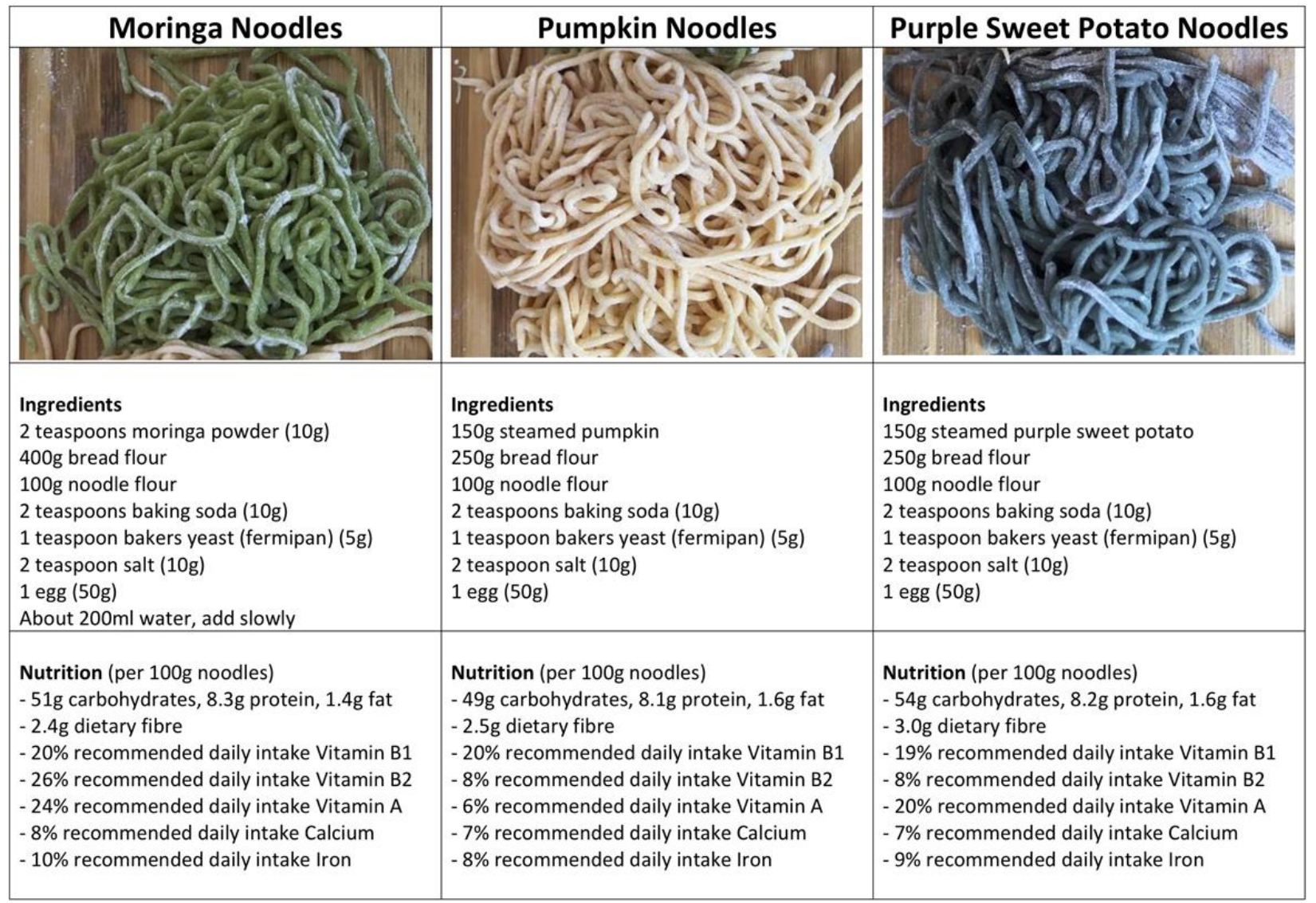

${ }^{11}$ A third youth member of the TLFIX team also experienced transformation as an outcome of the project. In 2022, just as this paper was going to press, Julio da Cunha launched his own business, aptly named “Timor Mie," which produces and sells the "recombinant" noodles for both dining in and takeout. 
training as well as operational revenue generation. ${ }^{12}$ The TLFL team went on to apply the TLFIX approach to other projects in Timor-Leste, in the Oecusse and Likisa Municipalities (with support from Oxfam and USAID, respectively), and in Maubisse (with support from The Asia Foundation).

The outcomes above suggest that "recombinance" may take many forms within food systems. Future-oriented change through the transformation of researchers, adaptive models of cooking and reflecting on taste, the weaving together of oral narrative and digital media, and the integration of small-scale, local businesses within the larger circles of international aid and development-all may be understood as merging past and present, local and transnational, outsider and Indigenous. Though largely unmeasurable in quantitative terms, such results suggest alternate ways of valorizing collaborative food research.

\section{Reflections and Conclusion}

As a pilot in the sphere of international development, TLFIX was designed to generate a series of outcomes that might be leveraged into ongoing international funding and expansion into a series of future initiatives. But it also aimed to work against the normativities of conventional development projects, in which individual empowerment may be less valued than the delivery of project reports (Peake, 2021). It achieved multiple goals, with impact in the media and in civil society, among the highest ranks of the national government, and on many individual lives, tastes, and capabilities. The TLFIX team members were themselves sought out for consultation on other food-related projects, and received numerous forms of attention and accolades.

These outcomes are perhaps more intriguing when understood as having emerged from a blend of scholarly, commercial, and development efforts, which mixed collaborators, objectives, and methods, and focused less on data-gathering and more on responding to whatever came next. The outcomes described above are only a partial portrait of what happens when responsiveness and relation- ality are supported. They are also illustrative of the genetic sense of recombinance, in which transformation today can produce evolutionarily improved "progeny" in the future. Tangible benefits will continue to be produced for the local participants and their communities, including knowledge outcomes, culinary and communications skills, and crosssector relationships, as well as increased pride, confidence, and curiosity. For the outsiders, numerous aspects of Timorese food and cultural heritage were surfaced. I now view the country as a set of deeply woven relationships among food, colonialism, pride/shame identities, and commercial-political-nutritional challenges. Furthermore, despite my theoretical understanding of "multiple knowledge paradigms," to be confronted with the ways in which knowing and showing are not directly translatable was both humbling and inspiring.

Despite and indeed because of its inherent risks, complexities, and challenges, food systems research presents opportunities for scholarly experimentation and reflection. As the broader project of academia as a whole is interrogated, food work also offers a space in which we might refigure the role of scholarship-perhaps more in service to the day-to-day needs of the communities and individuals with which academic researchers often engage. This may also lend support to projects that weave together multiple frameworks and deploy responsive and relational models; for example, projects in which local and outsider perspectives merge with practice-based and scholarly tools.

As a whole, TLFIX and its outcomes demonstrate that the mixing of research methodsscientific and embodied, messy and disciplinedand the involvement of collaborators with diverse knowledge paradigms can be effective modes of producing outcomes that are meaningful, rigorous, opportunistic, and just. Situated in a context of heterogeneous cultural identity, the work may also help move scholarship within and about postcolonial food contexts beyond simplistic dualities, and toward the reinforcement of difference and

\footnotetext{
12 As noted above, Lim and Notaras left Timor-Leste in 2020 due to the COVID pandemic, and Agora is now operated by an allTimorese staff.
} 
"Two-Eyed Seeing." That TLFIX produced recombinant outcomes, including formalized and embodied knowledge, as well as influences on policy development and day-to-day eating habits, supports the value of pluralism.

Because food systems are only increasing in complexity, moving toward pluralist approaches appears to be necessary. TLFIX may therefore serve as a useful reference for future efforts that embrace diversity, serendipity, and even uncertainty. As to the recombinant future of sweet potato flatbread and Timor Mie, time and taste will tell.

\section{Acknowledgments}

I am deeply grateful to the TLFIX and Agora communities for generously inviting me to participate in this project and for the trust they have shown me, including during the writing of this article. My special thanks to Dr. Lilly Cleary, for her thoughtful insights on clarifying the project description and for her ultra-keen editorial eye. I am also indebted to Dr. Irena Knezevic, Carleton University, and the School of Journalism and Communication, for their scholarly and community support. Thank you also to the anonymous reviewers who provided useful feedback.

\section{References}

Adejuwon, O. H., Jideani, A. I. O., \& Falade, K. O. (2020). Quality and public health concerns of instant noodles as influenced by raw materials and processing technology. Food Reviews International, 36(3), 276-317. https://doi.org/10.1080/87559129.2019.1642348

Andersen, A., Pant, J., \& Haraksingh, S. (2013). Food and nutrition security in Timor-Leste [Working paper]. WorldFish. https://hdl.handle.net/20.500.12348/906

Arthur, C. E. (2019). Political symbols and national identity in Timor-Leste. Palgrave Macmillan. https://doi.org/10.1007/978-3-319-98782-8

Atkins, P. (2010). Liquid materialities: A history of milk, science and the law. Ashgate.

Barrkman, J. (2014). The art of futus: Ikat weaving of Timor-Leste. Timor Aid.

Bartlett, C., Marshall, M., \& Marshall, A. (2012). Two-Eyed Seeing and other lessons learned within a co-learning journey of bringing together indigenous and mainstream knowledges and ways of knowing. Journal of Environmental Studies and Sciences, 2(4), 331-340. https://doi.org/10.1007/s13412-012-0086-8

Belasco, W. (2006). Meals to come: A history of the future of food. University of California Press.

Boje, D. M. (Ed.) (2011). Storytelling and the future of organizations: An antenarrative handbook. Routledge.

Bonis-Profumo, G., McLaren, R., \& Fanzo, J. (2019). Ravaged landscapes and climate vulnerability: The challenge in achieving food security and nutrition in post-conflict Timor-Leste. In D. Barling \& J. Fanzo (Eds.), Advances in food security and sustainability, vol. 4 (pp. 97-132). Elsevier. https://doi.org/10.1016/bs.af2s.2019.06.005

Borgerhoff, A. (2006). The double task: Nation- and state-building in Timor-Leste. European Journal of East Asian Studies, 5(1), 101-130. https://doi.org/10.1163/157006106777998098

Bortolin, K. (2011). Serving ourselves: How the discourse on community engagement privileges the university over the community. Michigan Journal of Community Service Learning, 18(1), 49-58. http://hdl.handle.net/2027/spo.3239521.0018.104

Bradley, K., \& Herrera, H. (2016). Decolonizing food justice: Naming, resisting, and researching colonizing forces in the movement. Antipode, 48(1), 97-114. https://doi.org/10.1111/anti.12165

Broad, G. M. (2020). Making meat, better: The metaphors of plant-based and cell-based meat innovation. Environmental Communication, 14(7), 919-932. https://doi.org/10.1080/17524032.2020.1725085

Callon, M. (1984). Some elements of a sociology of translation: Domestication of the scallops and the fishermen of St Brieuc Bay. The Sociological Review, 32(S1), 196-233. https://doi.org/10.1111/j.1467-954X.1984.tb00113.x

Castro, A. F. (2013). An approach to the food habits of three communities in Timor-Leste [Final report]. CARE International in Timor-Leste. https://care4.org.au/wp-content/uploads/2014/12/Timor-Leste-food-habits-report.pdf

Clifford, J. (1986). Introduction: Partial truths. In J. Clifford \& G. E. Marcus (Eds.), Writing culture: The poetics and politics of ethnography (pp. 1-26). University of California Press. 
Cole, A. (2017). Towards an indigenous transdisciplinarity. Transdisciplinary Journal of Engineering \& Science, 8, 127-150. https://doi.org/10.22545/2017/00091

Conquergood, D. (1989). Poetics, play, process, and power: The performative turn in anthropology. Text and Performance Quarterly, 9(1), 82-88. https://doi.org/10.1080/10462938909365914

Conquergood, D. (2002). Performance studies: Interventions and radical research. TDR/The Drama Review, $46(2$ (174)), 145-156. https://doi.org/10.1162/105420402320980550

de Certeau, M. (1984). The Practice of Everyday Life (Trans. Steven Rendall). University of California Press.

de Marchi, B. (1999). Pluralism and the complexity of knowledge. Politics and the Life Sciences, 18(2), 208-210. https://doi.org/10.1017/S0730938400021201

de Solier, I. (2013). Food and the self: Consumption, production and material culture. Bloomsbury Academic.

Denis, M. (2014). Exploring the management of biodiversity in Timor-Leste: A transdisciplinary approach [Unpublished master's thesis]. Lund University. https:/ / lup.lub.lu.se/luur/download?fileOId=4446646\&func=downloadFile\&recordOId=4446632

Dolejšová, M., Lišková, T., \& Obert, M. (2017, March 22). HotKarot \& OpenSauce: Edible storytelling \& design speculations. Research Through Design, National Museum of Scotland. https://www.academia.edu/31825988/HotKarot and OpenSauce Edible Storytelling and Design Speculations

Doonan, N. (2015). Techniques of making public: The Sensorium through eating and walking. Theatre Research in Canada, 36(1), 52-72. https://doi.org/10.3138/tric.36.1.52

Dunphy, K. (2013). Community arts in Timor-Leste 2001-2011. In M. Comte (Ed.), Community arts. (n. p.) Australian Scholarly Publishing.

Fischlin, D., \& Heble, A. (2004). The other side of nowhere: Jazz, improvisation, and communities in dialogue. In D. Fischlin \& A. Heble (Eds.), The other side of nowhere: Jazz, improvisation, and communities in dialogue (pp. 1-42). Wesleyan University Press.

Flicker, S. (2008). Who benefits from community-based participatory research? A case study of the Positive Youth Project. Health Education \& Behavior, 35(1), 70-86. https://doi.org/10.1177/1090198105285927

Florey, C., Hellin, J., \& Balié, J. (2020). Digital agriculture and pathways out of poverty: The need for appropriate design, targeting, and scaling. Enterprise Development and Microfinance, 31(2), 126-140. https://doi.org/10.3362/1755-1986.20-00007

General Directorate of Statistics. (2018). Timor-Leste Demographic and Health Survey 2016. Timor-Leste Ministry of Health, \& Ministry of Planning \& Finance, ICF Demographic and Health Surveys. https://www.dhsprogram.com/publications/publication-fr329-dhs-final-reports.cfm

Glick, B. R., \& Patten, C. L. (2017). Molecular biotechnology: Principles and applications of recombinant DNA (5 ${ }^{\text {th }} \mathrm{ed}$.). ASM Press.

Gibson-Graham, J. K. (2014). Rethinking the economy with thick description and weak theory. Current Anthropology, 55(Suppl. 9), S147-S153. https://doi.org/10.1086/676646

Guillaud, D., Emperaire, L., \& Bustamante, P. (2013). Heritage, agro-biodiversity and the local populations: Some examples from the use of palm trees in East Timor. In H. Loney, A. B. da Silva, N. C. Mendes, A. da Costa Ximenes, \& C. Fernandes (Eds.), Understanding Timor-Leste 2013 (pp. 183-189), Swinburne Press.

Guttal, S. (2009). New and old faces of hunger: Cambodia, Timor Leste, and food crises. Review (Fernand Braudel Center), 32(1), 61-89. https://www.jstor.org/stable/40647789

Haberman, D., Gillies, L., Canter, A., Rinner, V., Pancrazi, L., \& Martellozzo, F. (2014). The potential of urban agriculture in Montréal: A quantitative assessment. ISPRS International Journal of Geo-Information, 3(3), 1101-1117. https://doi.org/10.3390/ijgi3031101

Haraway, D. (1988). Situated knowledges: The science question in feminism and the privilege of partial perspective. Feminist Studies, 14(3), 575-599. https://doi.org/10.2307/3178066

Hart, M. A., Straka, S., \& Rowe, G. (2017). Working across contexts: Practical considerations of doing Indigenist/anticolonial research. Qualitative Inquiry, 23(5), 332-342. https://doi.org/10.1177/1077800416659084 
Howe, B. (2013). Rebuilding human security in Timor-Leste. In B. Howe, The protection and promotion of human security in East Asia (pp. 168-186). Palgrave Macmillan. https://doi.org/10.1057/9781137293657 8

Johnson, C. M. (2015). Gender, empowerment, and cultural preservation at Topu Honis Shelter Home, Timor-Leste. Gender, Place \& Culture, 22(10), 1408-1425. https://doi.org/10.1080/0966369X.2014.970134

Johnson, J. T. (2012). Place-based learning and knowing: Critical pedagogies grounded in Indigeneity. GeoJournal, 77(6), 829-836. https://doi.org/10.1007/s10708-010-9379-1

Johnston, R., McGregor, D., \& Restoule, J.-P. (2018). Indigenous research: Theories, practices, and relationships. Canadian Scholars Press.

Kepkiewicz, L., Levkoe, C. Z., \& Brynne, A. (2019). "Community first” for whom? Reflections on the possibilities and challenges of community-campus engagement from the Community Food Sovereignty Hub. Engaged Scholar Journal: Community-Engaged Research, Teaching, and Learning, 4(2), 43-60. https://doi.org/10.15402/esj.v4i2.61747

Law, J. (2004). After method: Mess in social science research. Routledge.

Leach, M. (2016). Nation-building and national identity in Timor-Leste. Taylor \& Francis.

Leeuwis, C., Boogaard, B. K., \& Atta-Krah, K. (2021). How food systems change (or not): Governance implications for system transformation processes. Food Security, 13(4), 761-780. https://doi.org/10.1007/s12571-021-01178-4

Levkoe, C. Z., Andrée, P., Bhatt, V., Brynne, A., Davison, K. M., Kneen, C., \& Nelson, E. (2016). Collaboration for transformation: Community-campus engagement for just and sustainable food systems. Journal of Higher Education Outreach and Engagement 20(3), 32-61. https://openjournals.libs.uga.edu/jheoe/article/view/1292

Levkoe, C. Z., Ray, L., \& Mclaughlin, J. (2019). The Indigenous food circle: Reconciliation and resurgence through food in northwestern Ontario. Journal of Agriculture, Food Systems, and Community Development, 9(B), 101-114. https://doi.org/10.5304/jafscd.2019.09B.008

Lien, M. E., \& Law, J. (2011). 'Emergent aliens': On salmon, nature, and their enactment. Ethnos, 76(1), 65-87. https://doi.org/10.1080/00141844.2010.549946

Mansfield, B. (2003). 'Imitation crab' and the material culture of commodity production. Cultural Geographies, 10(2), 176-195. https://doi.org/10.1191/1474474003eu261oa

McGregor, A. (2007). Development, foreign aid and post-development in Timor-Leste. Third World Quarterly, 28(1), 155-170. https://doi.org/10.1080/01436590601081955

Miller, D. (Ed.) (2005). Materiality. Duke University Press.

Miller, L., Luchs, M., \& Jalea, G. D. (2011). Mapping memories: Participatory media, place-based stories \& refugee youth. Marquis.

Mingers, J. (1994). Self-producing systems: Implications and applications of autopoiesis. Springer Science \& Business Media.

Molnar, A. K. (2010). Timor Leste: Politics, history, and culture. Routledge.

Montuori, A., \& Donnelly, G. (2016). The creativity of culture and the culture of creativity research: The promise of integrative transdisciplinarity. In V. P. Glăveanu (Ed.), The Palgrave handbook of creativity and culture research (pp. 743765). Palgrave Macmillan. https://doi.org/10.1057/978-1-137-46344-9 36

Murta, J., \& Willetts, J. (2014). Incentives for enterprise engagement in Timor-Leste: Private and social enterprise engagement in water and sanitation for the poor (Working paper 2c). University of Technology, Sydney. https://opus.lib.uts.edu.au/handle/10453/33824

Oomen, J., Hoffman, J., \& Hajer, M. A. (2021). Techniques of futuring: On how imagined futures become socially performative. European Journal of Social Theory. https://doi.org/10.1177/1368431020988826

Peake, G. (Host). (2021, Jan. 31). MoU food: An entrée to development (Memorandum of Understanding (MoU) Episode 1)[Audio podcast]. https:// memorandum-of-understanding.simplecast.com/

Pereira, E. (2019, Oct. 25). Filipe da Costa, Reprezentante Espesiál ba Seguransa Ai-han no Nutrisaun (Filipe da Costa, Special Representative for Food Security and Nutrition). TATOLI: Agência Noticiosa de Timor-Leste. http:/ / www.tatoli.tl/2019/10/25/filipe-da-costa-reprezentante-espesial-ba-seguransa-ai-han-no-nutrisaun/

Provo, A., Atwood, S., Sullivan, E. B., \& Mbuya, N. (2017). Malnutrition in Timor-Leste: A review of the burden, drivers, and potential response (Working paper). World Bank Group. http://hdl.handle.net/10986/26394 
Ritenburg, H., Leon, A. E. Y., Linds, W., Nadeau, D. M., Goulet, L. M., Kovach, M., \& Marshall, M. (Meri). (2014). Embodying decolonization: Methodologies and Indigenization. AlterNative: An International Journal of Indigenous Peoples, 10(1), 67-80. https://doi.org/10.1177/117718011401000107

Romm, N. (2020). Researching Indigenous ways of knowing-and-being: Revitalizing relational quality of living. In I. R. Management Association (Ed.), Indigenous studies: breakthroughs in research and practice (pp. 407-434). IGI Global. https://doi.org/10.4018/978-1-7998-0423-9

Santich, B. (1996). Sustaining gastronomy. In B. Santich, J. Hillier, C. Kerry (Eds.), Proceedings of the Eighth Symposium of Australian Gastronomy: Sustaining gastronomy, Adelaide, September 28-30, 1994 (pp. 1-2).

Siapno, J. A. (2013). 'A society with music is a society with hope': Musicians as survivor-visionaries in post-war Timor Leste. South East Asia Research, 21(3), 439-455. https://doi.org/10.5367/sear.2013.0167

Smith, L. T. (2013). Decolonizing methodologies: Research and Indigenous peoples (2 ${ }^{\text {nd }}$ ed.). Zed Books.

Steeves, P. F. (2018). Indigeneity. Oxford Bibliographies Online: Anthropology. https://doi.org/10.1093/obo/9780199766567-0199

Stefanovic, L., Freytag-Leyer, B., \& Kahl, J. (2020). Food system outcomes: An overview and the contribution to food systems transformation. Frontiers in Sustainable Food Systems, 4(546167). https://doi.org/10.3389/fsufs.2020.546167

Strand, K. J., Cutforth, N., Stoecker, R., Marullo, S., \& Donohue, P. (2003). Community-based research and higher education: Principles and practices. Jossey-Bass.

Szanto, D. (2016, May 31-June 1). Eater or eaten: What revolves around who? In M. M. C. Iomaire (Chair), Food and Revolution [Symposium], Dublin Gastronomy Symposium 3rd Biennial Symposium, Dublin Institute of Technology, Ireland. http: / / arrow.dit.ie/cgi/viewcontent.cgi?article=1071\&context $=\mathrm{dgs}$

Szanto, D. (2018). Blurred, broken, and bewildered: What performing with food does with the lines around performance and food studies. In/Tensions, (9). https://bit.ly/BlurredBroken

Szerszynski, B., Heim, W., \& Waterton, C. (2003). Introduction. In B. Szerszynski, W. Heim, \& C. Waterton (Eds.), Nature performed: Environment, culture and performance (pp. 1-14). Blackwell.

Timor-Leste Food Innovators Exchange (TLFIX). (2018). ABOUT TLFIX-Timor-Leste Food Lab. Timor-Leste Food Lab/Agora Food Studio. https://www.timorlestefoodlab.com/blog/2018/11/27/what-is-tlfix

Timor-Leste Ministry of Health. (2014). Timor-Leste National Nutrition Strategy 2014-2019.World Health Organization, Global Database on the Implementation of Nutrition Action (GINA). https://extranet.who.int/nutrition/gina/en/node/23608

Todd, C. (2018). Tasting in time: The affective and temporal dimensions of flavour perception. The Monist, 101(3), 277293. https://doi.org/10.1093/monist/ony006

United Nations Development Programme Timor-Leste. (2019, December 4). First Youth Co:Lab Timor-Leste National Youth Forum launched in Timor-Leste. UNDP. https://www.tl.undp.org/content/timor leste/en/home/newscentre/pressreleases/2019/first-youth-co-lab-timorleste-national-youth-forum-launched-in-.html

Wilcove, D. S., \& Koh, L. P. (2010). Addressing the threats to biodiversity from oil-palm agriculture. Biodiversity and Conservation, 19(4), 999-1007. https://doi.org/10.1007/s10531-009-9760-X

Wilson, S. (2009). Research is ceremony: Indigenous research methods. Fernwood.

Youth Co:Lab. (2020). Youth Co:Lab springboard programme. Youth Co:Lab Learning Management System. https://www.youthcolab-springboard.org/ 